\title{
Corn with Symptoms of Reddening: New Host of Stolbur Phytoplasma
}

\author{
B. Duduk, Agriculture Research Institute „Serbia“, Pesticide and Environmental Research Centre, Banatska 31b, \\ 11080 Belgrade-Zemun, Serbia; and A. Bertaccini, DiSTA, Patologia Vegetale, Alma Mater Studiorum, University \\ of Bologna, viale Fanin 42, 40127 Bologna, Italy
}

\begin{abstract}
Duduk, B., and Bertaccini, A. 2006. Corn with symptoms of reddening: New host of stolbur phytoplasma. Plant Dis. 90:1313-1319.

Recurrent epiphytotic outbreaks of a disease of uncertain etiology known as reddening of corn (Zea mays) have occurred in some areas of Serbia during the last 50 years. Affected plants show early and abnormal ripening, dry precociously, and have poor, shriveled grains. Using molecular tools, phytoplasmas were detected in diseased plants and their identity was subsequently deduced as a subgroup 16SrXII-A strain by a variety of supporting assays involving restriction fragment length polymorphism (RFLP) analysis of polymerase chain reaction (PCR)-amplified $16 \mathrm{~S}$ rDNA and tuf gene sequences, selective amplification of phytoplasma DNA using primer pair G35p/m, similarity of 16-23S intergenic spacer region (SR) sequences, and similarity and phylogenetic analysis of 16S rDNA gene sequences. Presence of stolbur phytoplasmas in corn with reddening symptoms is a new finding not only for Serbia: it is the first report of stolbur phytoplasma in this species worldwide.
\end{abstract}

Reddening of corn (Zea mays L.) was observed for the first time in 1957 in the middle south Banat region of Serbia in Europe (20). After the first sporadic appearance in 1957, the disease entered into an epidemic phase during the late 1950s and early 1960s. Another epidemic phase in the same region was reported 40 years later, during the late 1990s and early 2000s. Between these epidemic phases, the disease was always present sporadically in the region (31), although it appeared to be more widespread in dry years, and it was reported as the most important disease of corn in the region due to its impact on yield $(3,31)$.

During the epidemic phase, disease symptoms can be present in up to $90 \%$ of the plants, and yield losses can be over $50 \%$ (28). Symptoms of reddening begin in the second half of July on the main leaf midrib; then they spread to the stalk and eventually affect the whole plant. The most obvious symptoms are present in August and September (30). Symptomatic plants have the same size and shape as asymptomatic ones, but disease reduces grain filling and corn cob weight. Symptomatic plants contain poor, shriveled grains that ripen and dry earlier than asymptomatic ones.

Corresponding author: B. Duduk

E-mail: duduk@net.yu

GenBank accession numbers of DNA sequences: DQ239437, DQ222972.

Accepted for publication 31 May 2006.

DOI: 10.1094/PD-90-1313

(C) 2006 The American Phytopathological Society
Phytoplasmas are prokaryotes with phloematic habitats found throughout the world in wild and cultivated plants. Typical symptoms include yellowing, discoloration, witches'-broom, dwarfing, virescence, and phyllody. In nature, phytoplasmas are transmitted by leafhoppers (Auchenorrhyncha) that may have occasional or permanent trophic relationships with their hosts.

The reddening symptoms observed on corn, the presence of recurrent epidemic outbreaks, and the characteristics of disease development, in particular the fact that symptoms always appear first around the border of fields, suggesting infections from outside the field through vectors, indicate a possible association of the syndrome with phytoplasmas, even though phytoplasma presence in corn has generally been associated with stunting symptoms.

Throughout the world, two diseases associated with Mollicutes have been reported in corn: maize bushy stunt (MBS) and corn stunt (CS), both present in North, Central, and South America $(10,12,19)$. MBS is associated with a phytoplasma that is a member of the aster yellows 16SrI-B ribosomal subgroup (19). CS is a disease caused by Spiroplasma kunkelii $(5,35)$. These pathogens are both transmitted by the cicadellid leafhopper Dalbulus maidis and by other Dalbulus spp. (10).

Preliminary experiments indicating the possible infective nature of reddening of corn (28), and suggestions by other authors of association of this syndrome with phytoplasmas $(3,29)$, stimulated research to verify the possibility of association of this disease with a phytoplasma.

\section{MATERIALS AND METHODS}

Sample collection and nucleic acid extraction. Sixteen samples of symptomatic, and four of asymptomatic, corn plants were collected during the second half of August 2005 in the south Banat region of Serbia (Table 1). Total nucleic acids were extracted from $1 \mathrm{~g}$ of main leaf midribs and phloem stalk tissues following the protocol described by Prince et al. (25), dissolved in TE buffer, and maintained at $4^{\circ} \mathrm{C}$. Before performing polymerase chain reaction (PCR) assays, nucleic acids were quantified and diluted in sterile distilled water to a final concentration of $20 \mathrm{ng} / \mu \mathrm{l}$.

Reference phytoplasma strains. The 18 phytoplasmas used as reference strains were primula phyllody (PRIVA, ribosomal subgroup 16SrI-B), clover phyllody (KVG, ribosomal subgroup $16 \mathrm{SrI}-\mathrm{C}$ ), aster yellows from apricot (AY-A, ribosomal subgroup 16SrI-F), faba bean phyllody (FBPSA, ribosomal subgroup 16SrII-C), Green Valley X disease (GVX, ribosomal subgroup 16SrIII-A), elm yellows (EY-C, ribosomal subgroup $16 \mathrm{SrV}-\mathrm{A})$, Catharanthus phyllody from Sudan (CPS, ribosomal subgroup 16SrVI-C), ash yellows (ASHY1, ribosomal subgroup 16SrVII-A, "Candidatus Phytoplasma fraxini”), Pichris echioides yellows (PEY, ribosomal group 16SrIX), flower stunting (BVK, ribosomal subgroup 16SrXI-C), apple proliferation (AP-15, ribosomal subgroup 16rX-A, " $\mathrm{Ca}$. P. mali"), German European stone fruit yellows (GSFY/1, ribosomal subgroup 16SrX-B, " $\mathrm{Ca}$. P. prunorum"), pear decline (PD, ribosomal subgroup $16 \mathrm{SrX}-\mathrm{C}$, “Ca. $\mathrm{P}$. pyri”), and stolbur from pepper from Serbia (STOL, ribosomal subgroup 16SrXIIA). These strains represent the majority of ribosomal phytoplasma groups described in the literature $(16,18)$ and have been employed for phytoplasma identification in other studies. They were maintained in in vitro periwinkle (Catharanthus roseus $(\mathrm{G}$.) Don.) shoots in the phytoplasmology laboratory of DiSTA (University of Bologna, Italy, EU).

Further phytoplasma positive controls were strain VE16, from grapevine cv. Chardonnay collected in Venice province, Italy; strains MO-2 and MO-47 from grapevine cv. Lambrusco collected in Modena province, Italy; and strain P1 from grapevine cv. Chardonnay collected in Serbia (9). These samples represent the nucleic acids extracted from grapevine infected by "Bois noir" disease phytoplasmas (ribosomal subgroup 16SrXII-A) 
and were only employed for restriction fragment length polymorphism (RFLP) characterization of the tuf gene, which is described below.

16S Ribosomal DNA. Detection of phytoplasmas was done using PCR assays with phytoplasma universal primer pair $\mathrm{P} 1 / \mathrm{P} 7(8,27)$ in direct PCR reaction, followed by nested PCR with F1/B6 primers $(6,24)$. Further nested PCR reactions on P1/P7 amplicons were performed with R16(I)F1/R1 (17) primer pair, specific for phytoplasmas belonging to aster yellows (16SrI) (17), faba bean phyllody (16SrII) (33), and stolbur (16SrXII) (sensu 16) groups.

Each $25-\mu$ PCR reaction mix contained $20 \mathrm{ng}$ of template DNA, $2.5 \mu \mathrm{l}$ of $10 \times$ PCR buffer, $0.8 \mathrm{U}$ of Taq polymerase (Polymed, Italy, EU), $0.2 \mathrm{mM}$ dNTPs, $1.5 \mathrm{mM}$ $\mathrm{MgCl}_{2}$, and $0.4 \mathrm{mM}$ each primer. Samples lacking DNA were run as negative controls in each PCR reaction. One microliter of amplicon from direct PCR, diluted 1:30 in sterile distilled water, was used as template in nested PCR reactions. Thirty-five PCR cycles were performed under the following conditions: $1 \mathrm{~min}$ ( $2 \mathrm{~min}$ for the first cycle) for denaturation at $94^{\circ} \mathrm{C}, 2 \mathrm{~min}$ for annealing at $50^{\circ} \mathrm{C}$, and $3 \mathrm{~min}(10 \mathrm{~min}$ for the last cycle) for primer extension at $72^{\circ} \mathrm{C}$. Six microliters of PCR products were separated in $1 \%$ agarose gel, stained with ethidium bromide, and photographed under UV at $312 \mathrm{~nm}$ using a transilluminator.

Identification of detected phytoplasmas was done using RFLP analyses with TruI and TaqI restriction enzymes on amplified ribosomal DNA sequences. Visualization of RFLP products was performed in a $5 \%$ polyacrylamide gel, stained with ethidium bromide, and visualized with UV transilluminator.

P1/P7 amplified product (about 1,800 bp) of sample 2005/2 was purified using Qiagen PCR Purification Kit (Qiagen GmbH, Hilden, Germany, EU). The PCR product was sequenced in both directions using the BIG DYE sequencing terminator kit (PE Biosystems, Warrington, UK). Sequence of the purified sample was obtained from PCR products generated by amplification with primers P1, R16F2, and P7 in the Centro Ricerche Interdipartimentale Biotecnologie Innovative (C.R.I.B.I. Padua, Italy, EU). The sequences were then aligned using BLAST engine for local alignment (version Blast $\mathrm{N}$ 2.2.12). The gene sequence (1,648 bp) obtained was deposited in the National Center for Biotechnology Information (NCBI, Bethesda, MD, USA) under accession no. DQ222972.

The publicly available alignments of "Candidatus Phytoplasma" species 16S rDNA sequences were downloaded from TreeBase (University at Buffalo, NY, USA, matrix accession no. M1788), and 16S rDNA sequences of additional phytoplasmas were aligned using BioEdit (11), which was also used to calculate sequence identity values for the spacer region. A phylogenetic tree was then constructed using CLUSTALX program (32) for aligning corn sample 2005/2 16S sequence with $16 \mathrm{~S}$ ribosomal gene sequences from 29 representative strains of the genus " $\mathrm{Candi}$ datus Phytoplasma" (13); bootstrap analysis was also performed and replicated 100 times (Table 2). Acholeplasma palmae, a

Table 1. Phytoplasmas detected in corn with reddening and the different phytoplasma DNA fragments amplified using polymerase chain reaction (PCR)

\begin{tabular}{|c|c|c|c|c|c|}
\hline \multirow[b]{2}{*}{ Sample ${ }^{a}$} & \multicolumn{2}{|r|}{ 16Sr DNA } & \multicolumn{2}{|c|}{ Tuf gene } & \multirow{2}{*}{$\begin{array}{c}\text { Chromosomal } \\
\text { DNA }\end{array}$} \\
\hline & P1/P7 & F1/B6 ${ }^{b}$, R16(I)F1/R1 ${ }^{b}$ & Tuf1f/r & TufAYf $/ \mathbf{r}^{b}$ & \\
\hline $2005 / 1^{\mathrm{S}}$ & + & + & + & + & + \\
\hline $2005 / 2^{\mathrm{S}}$ & + & + & + & + & + \\
\hline $2005 / 3^{S}$ & - & + & - & + & - \\
\hline $2005 / 4^{S}$ & + & + & + & + & + \\
\hline $2005 / 5^{\mathrm{s}}$ & + & + & + & + & + \\
\hline $2005 / 6^{\mathrm{S}}$ & + & + & + & + & + \\
\hline $2005 / 7^{\mathrm{S}}$ & - & + & - & + & - \\
\hline $2005 / 8^{S}$ & - & + & - & + & - \\
\hline $2005 / 9^{S}$ & + & + & + & + & + \\
\hline $2005 / 10^{\mathrm{S}}$ & - & + & - & + & - \\
\hline $2005 / 11^{\mathrm{S}}$ & + & + & + & + & + \\
\hline $2005 / 12^{\mathrm{S}}$ & + & + & + & + & + \\
\hline $2005 / 13^{\mathrm{S}}$ & + & + & + & + & + \\
\hline $2005 / 14^{S}$ & + & + & + & + & + \\
\hline $2005 / 15^{\mathrm{S}}$ & + & + & + & + & + \\
\hline $2005 / 16^{\mathrm{S}}$ & + & + & + & + & + \\
\hline $2005 / 17^{\mathrm{A}}$ & - & - & - & - & - \\
\hline $2005 / 18^{\mathrm{A}}$ & - & - & - & - & - \\
\hline $2005 / 19^{\mathrm{A}}$ & - & - & - & - & - \\
\hline $2005 / 20^{\mathrm{A}}$ & - & - & - & - & - \\
\hline Total symptomatic ${ }^{c}$ & $12 / 16$ & $16 / 16$ & $12 / 16$ & $16 / 16$ & $12 / 16$ \\
\hline Total asymptomatic ${ }^{c}$ & $0 / 4$ & $0 / 4$ & $0 / 4$ & $0 / 4$ & $0 / 4$ \\
\hline
\end{tabular}

${ }^{\text {a } \mathrm{S}}=$ Symptomatic; ${ }^{\mathrm{A}}=$ asymptomatic. The strain subjected to sequencing is in bold.

${ }^{\mathrm{b}}$ Nested PCR.

c Number positive/number tested. cultivable Mollicute that is phylogenetically related to phytoplasmas, was designated as the out-group to root the tree.

Corn 2005/2 phytoplasma spacer region sequence was compared with the spacer region sequences of $A$. palmae and of 12 other phytoplasma strains retrieved from GenBank and phylogenetically related to 16SrXII group phytoplasmas or to corn diseases associated with phytoplasmas: Australian grapevine yellows (AGY, ribosomal subgroup 16SrXII-B); papaya dieback disease (PDD); Mexican periwinkle virescence (MPV, ribosomal group 16SrXIII); strawberry lethal yellows from Australia (StrawLY, ribosomal subgroup 16SrXII-B); strawberry green petals from Australia (StrawGP, ribosomal subgroup 16SrXII-B); maize bushy stunt (MBS, ribosomal subgroup 16SrI-B); barley deformation phytoplasma $(\mathrm{BaD}$, ribosomal subgroup 16SrI-B); chinaberry yellows from Bolivia (CbY1); stolbur phytoplasma from pepper from Serbia (STOL, ribosomal subgroup 16SrXII-A); grapevine yellows phytoplasma from Chile clone $b$ (GYb, ribosomal group 16SrXII); grapevine yellows phytoplasma from Spain (GY-S, ribosomal subgroup 16SrXII-A); and grapevine yellows phytoplasma from Chile clone a (GYa, ribosomal subgroup 16SrXII-A) (Table 3).

Tuf gene. Further molecular characterization of detected phytoplasmas was carried out on the tuf gene. Direct PCR reaction with the Tuf1f/Tuf1r primer pair was followed by nested PCR with TufAyf/TufAyr primer pair (26). Direct PCR was performed for 35 cycles under the following conditions: $30 \mathrm{~s}$ denaturation at $95^{\circ} \mathrm{C}, 30 \mathrm{~s}$ annealing at $45^{\circ} \mathrm{C}$, and $1 \mathrm{~min}$ primer extension at $72^{\circ} \mathrm{C}$. The conditions for nested PCR were the same except that the annealing temperature was $55^{\circ} \mathrm{C}(26)$; each $25-\mu l$ PCR of master mix was as described above. Six microliters of PCR products were separated in $1 \%$ agarose gel, and PCR products were subjected to RFLP analyses with TruI and HpaII restriction enzymes (Fermentas, Vilnius, Lithuania, EU); fragments were separated in 5\% polyacrylamide gel and photographed as described above.

Other chromosomal DNA. G35p/m primer pair, obtained by random cloning of DNA from phytoplasmas belonging to 16SrXII-A ribosomal subgroup (7), was used in direct PCR under the following conditions: $1 \mathrm{~min}$ ( $2 \mathrm{~min}$ for the first cycle) of denaturation at $94^{\circ} \mathrm{C}, 2 \mathrm{~min}$ of annealing at $50^{\circ} \mathrm{C}$, and $3 \mathrm{~min}(10 \mathrm{~min}$ for the last cycle) of primer extension at $72^{\circ} \mathrm{C}$; each $25 \mu \mathrm{l}$ PCR of master mix was as described above. PCR amplification was followed by RFLP analyses with TruI, Tsp509I, and $A l u \mathrm{I}$ restriction enzymes (Fermentas). $\mathrm{G} 35 \mathrm{p} / \mathrm{m}$ amplified product (about 1,200 bp) of sample 2005/2 was purified, sequenced using primer G35p and G35m, and aligned as described above. The gene 
sequence (751 bp) obtained (C.R.I.B.I. Padua, Italy, EU), was deposited in the NCBI under accession no. DQ239437, and aligned with those of phytoplasmas and other prokaryotes available in GenBank using BLAST engine for local alignment for Nucleotide-nucleotide BLAST (blastn), and translated query vs. protein database (blastx).

\section{RESULTS}

16S Ribosomal DNA. After direct amplification with $\mathrm{P} 1 / \mathrm{P} 7$ primer pair, fragments of $1,880 \mathrm{bp}$ were obtained from 12 of 16 samples collected from symptomatic corn plants, while none of the four samples collected from asymptomatic plants gave amplification (Table 1). Nested PCR reactions with $\mathrm{F} 1 / \mathrm{B} 6$ and $\mathrm{R} 16(\mathrm{I}) \mathrm{F} 1 / \mathrm{R} 1$ primer pairs both resulted in expected length fragment amplification for phytoplasmas (respectively about 1,700 and 1,100 bp) from all the symptomatic samples tested; no amplification was obtained from asymptomatic samples (Table 1). All 12 samples positive in direct PCR with P1/P7 primer pair showed restriction profiles when subjected to RFLP analyses with

Table 2. Phytoplasma 16S rDNA sequences retrieved from GenBank, including DQ222972 (corn sample 2005/2 from Serbia), and used for phylogenetic analysis

\begin{tabular}{|c|c|c|c|c|}
\hline Accession no. & Phytoplasma strain & Origin & Plant host & 16S rRNA group ${ }^{a}$ \\
\hline AY265208 & Maize bushy stunt (MBS) & Ohio (USA) & Corn & 16 SrI-B \\
\hline AF487779 & Maize bushy stunt (MBS) & Mexico & Corn & 16 SrI-B \\
\hline M30790 & "Candidatus Phytoplasma asteris" & Michigan (USA) & Oenothera spp. & 16SrI-B \\
\hline U15442 & "Ca. P. aurantifolia" & Oman & Lime & 16SrII-B \\
\hline L04682 & “Ca.P. pruni”’ & California (USA) & Peach & 16SrIII-A \\
\hline U18747 & "Ca. P. palmae"b & Florida (USA) & Veitchia merrillii & 16SrIV \\
\hline X80117 & "Ca. P. cocostanzianae"b & Tanzania & Cocos nucifera & 16 SrIV \\
\hline Y14175 & "Ca. P. cocosnigerianae"b & Nigeria & Cocos nucifera & 16 SrIV \\
\hline AF515637 & "Ca. P. phoenicium" & Iran & Almond & $16 \operatorname{SrIX}$ \\
\hline AF122910 & "Ca. P. ulmi" & New York (USA) & Elm & $16 \mathrm{SrV}-\mathrm{A}$ \\
\hline AF305240 & "Ca. P. ziziphi" & South Korea & Jujube & $16 \mathrm{SrV}-\mathrm{B}$ \\
\hline X76560 & “Ca. P. vitis"b & France (EU) & Grapevine & $16 \mathrm{SrV}-\mathrm{C}$ \\
\hline AY390261 & "Ca. P. trifolii" & Canada & Clover & 16SrVI-A \\
\hline AF092209 & "Ca. P. fraxini" & New York (USA) & Ash & 16SrVII-A \\
\hline AF086621 & "Ca. P. luffae"b & Taiwan & Luffa & 16SrVIII-A \\
\hline AJ542541 & "Ca. P. mali" & Italy (EU) & Apple & $16 \mathrm{SrX}-\mathrm{A}$ \\
\hline AJ542544 & "Ca.P. prunorum" & Germany (EU) & Peach & $16 \mathrm{SrX}-\mathrm{B}$ \\
\hline AJ542543 & “Ca.P. pyri” & Germany (EU) & Pear & $16 \mathrm{SrX}-\mathrm{C}$ \\
\hline X92869 & "Ca. P. spartii" & Italy (EU) & Spartium junceum & 16SrX-D \\
\hline D12581 & "Ca. P. oryzae" & Japan & Rice & 16SrXI-A \\
\hline AF248959 & "Ca.P. solani" & Serbia & Periwinkle from pepper & 16SrXII-A \\
\hline L76865 & "Ca. P. australiense" & Australia & Grapevine & 16SrXII-B \\
\hline AF147708 & "Ca. P. brasiliense" & Brazil & Hibiscus & $16 \mathrm{SrXV}$ \\
\hline DQ222972 & Corn $2005 / 2$ & Serbia & Corn & 16SrXII-A \\
\hline AJ310849 & "Ca. P. pini" & Germany (EU) & Pinus sylvestris & n.d. \\
\hline AB010425 & "Ca. P. japonicum" & Japan & Hydrangea & n.d. \\
\hline X76431 & "Ca.P. rhamni”" & Germany (EU) & Rhamnus frangula & n.d. \\
\hline AY135523 & "Ca. P. allocasuarinae" & Australia & Allocasuarina muelleriana & n.d. \\
\hline AJ550984 & "Ca. P. cynodontis" & Italy (EU) & Cynodon dactylon & n.d. \\
\hline AB054986 & "Ca. P. castaneae" & South Korea & Chestnut & n.d. \\
\hline
\end{tabular}

a "Candidatus" names proposed at the X International Congress of the International Organization of Mycoplasmology, 1994, held in Bordeaux, France, but not yet formally described, reported here as incidental citations that do not constitute prior citations according to rule $28 \mathrm{~b}$ of the bacteriological code (15).

${ }^{\mathrm{b}}$ n.d. $=$ ribosomal subgroup not determined.

Table 3. Analysis of sequence similarities among 14 spacer region sequences from phytoplasma detected in corn sample 2005/2 and 12 phytoplasmas, most of which belonged to $16 \mathrm{SrXII}$ group

\begin{tabular}{|c|c|c|c|c|c|c|c|c|c|c|c|c|c|c|c|}
\hline $\begin{array}{l}\text { GenBank accession no. } \\
\text { phytoplasma strains }{ }^{\mathrm{a}}\end{array}$ & $\begin{array}{c}16 \mathrm{~S} \\
\text { ribosomal } \\
\text { grouping b,c }\end{array}$ & 1 & 2 & 3 & 4 & 5 & 6 & 7 & 8 & 9 & 10 & 11 & 12 & 13 & 14 \\
\hline 1. X95706-AGY & 16SrXII-B & ID & 0.994 & 0.923 & 0.994 & 0.994 & 0.72 & 0.725 & 0.896 & 0.905 & 0.894 & 0.905 & 0.911 & 0.911 & 0.586 \\
\hline 2. Y10095 & n.d. & 0.994 & ID & 0.929 & 1 & 1 & 0.72 & 0.725 & 0.896 & 0.905 & 0.894 & 0.905 & 0.911 & 0.911 & 0.591 \\
\hline 3. AF025428-MPV & $16 \mathrm{SrXIII}$ & 0.923 & 0.929 & ID & 0.929 & 0.929 & 0.701 & 0.706 & 0.894 & 0.921 & 0.909 & 0.921 & 0.927 & 0.927 & 0.574 \\
\hline 4. AJ243045 StrawLY & $16 \mathrm{SrXII}-\mathrm{B}^{\mathrm{c}}$ & 0.994 & 1 & 0.929 & ID & 1 & 0.72 & 0.725 & 0.896 & 0.905 & 0.894 & 0.905 & 0.911 & 0.911 & 0.591 \\
\hline 5. AJ2430444 StrawGP & $16 \mathrm{SrXII}-\mathrm{B}^{\mathrm{c}}$ & 0.994 & 1 & 0.929 & 1 & ID & 0.72 & 0.725 & 0.896 & 0.905 & 0.894 & 0.905 & 0.911 & 0.911 & 0.591 \\
\hline 6. AF487779 MBS & 16SrI-B & 0.72 & 0.72 & 0.701 & 0.72 & 0.72 & ID & 0.99 & 0.741 & 0.703 & 0.698 & 0.703 & 0.708 & 0.708 & 0.545 \\
\hline 7. AY734453 BaD & 16SrI-B & 0.725 & 0.725 & 0.706 & 0.725 & 0.725 & 0.99 & ID & 0.746 & 0.708 & 0.703 & 0.708 & 0.712 & 0.712 & 0.549 \\
\hline 8. A & & 0.896 & 0.896 & 0.894 & 0.896 & 0.896 & 0.741 & 0.746 & ID & 0.904 & 0.903 & 0.904 & 0.91 & 0.91 & 0.572 \\
\hline 9. AY739654 GYa & 16SrXII-A & 0.905 & 0.905 & 0.921 & 0.905 & 0.905 & 0.703 & 0.708 & 0.904 & ID & 0.987 & 0.987 & 0.993 & 0.993 & 0.558 \\
\hline 10. AY739653 GYb & 16SrXII & 0.894 & 0.894 & 0.909 & 0.894 & 0.894 & 0.698 & 0.703 & 0.903 & 0.987 & ID & 0.975 & 0.981 & 0.981 & 0.558 \\
\hline 11. AJ964960 GY-S & 16SrXII-A & 0.905 & 0.905 & 0.921 & 0.905 & 0.905 & 0.703 & 0.708 & 0.904 & 0.987 & 0.975 & ID & 0.993 & 0.993 & 0.558 \\
\hline 12. AF248959 STOL & 16SrXII-A & 0.911 & 0.911 & 0.927 & 0.911 & 0.911 & 0.708 & 0.712 & 0.91 & 0.993 & 0.981 & 0.993 & ID & 1 & 0.563 \\
\hline 13. DQ222972 Corn $2005 / 2$ & 16SrXII-A & 0.911 & 0.911 & 0.927 & 0.911 & 0.911 & 0.708 & 0.712 & 0.9 & 0.993 & 0.981 & 0.993 & & ID & 0.563 \\
\hline 14. Acholeplasma palmae & & 0.586 & 0.591 & 0.574 & 0.591 & 0.591 & 0.545 & 0.549 & 0.572 & 0.558 & 0.558 & 0.558 & 0.563 & 0.563 & ID \\
\hline
\end{tabular}

a AGY, Australian grapevine yellows; PDD, Papaya dieback disease; MPV, Mexican periwinkle virescence; StrawLY, Strawberry lethal yellows; StrawGP, Strawberry green petals; MBS, Maize bushy stunt; BaD, Barley deformation phytoplasma; CbY1, Chinaberry yellows; GYa, Grapevine yellows phytoplasma clone a; GYb, Grapevine yellows phytoplasma clone b; GY-S, Grapevine yellows from Spain; STOL, stolbur phytoplasma from pepper from Serbia.

${ }^{\mathrm{b}}$ n.d. = ribosomal subgroup not determined.

${ }^{\mathrm{c}}$ Ribosomal subgroup proposed here. 
A

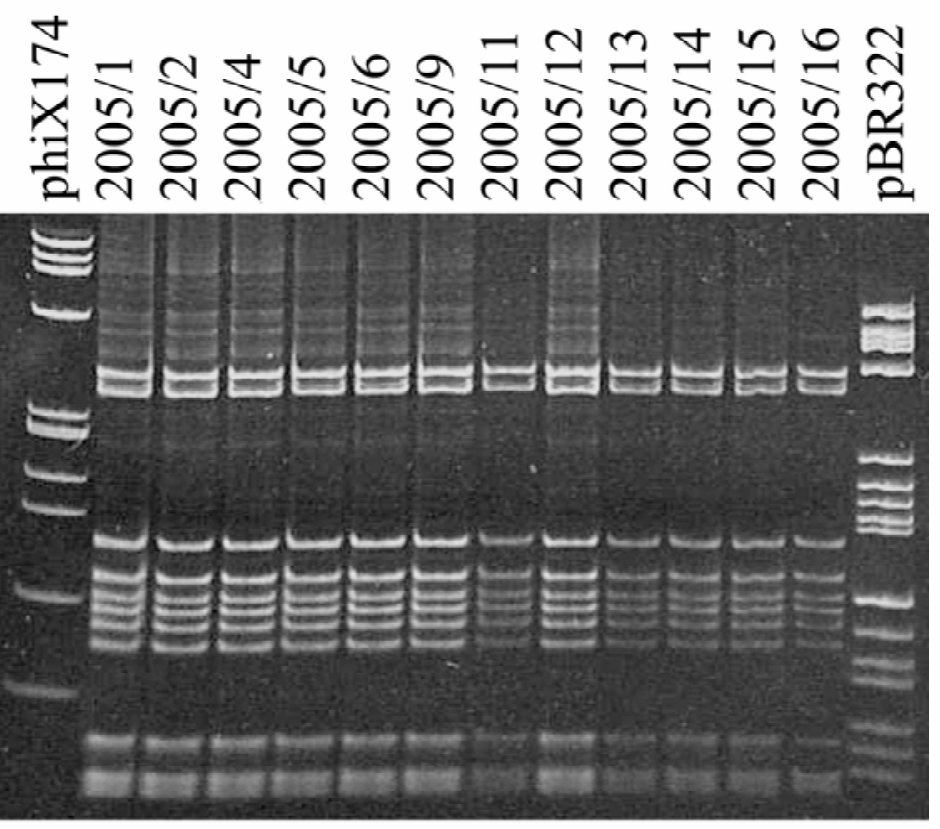

B
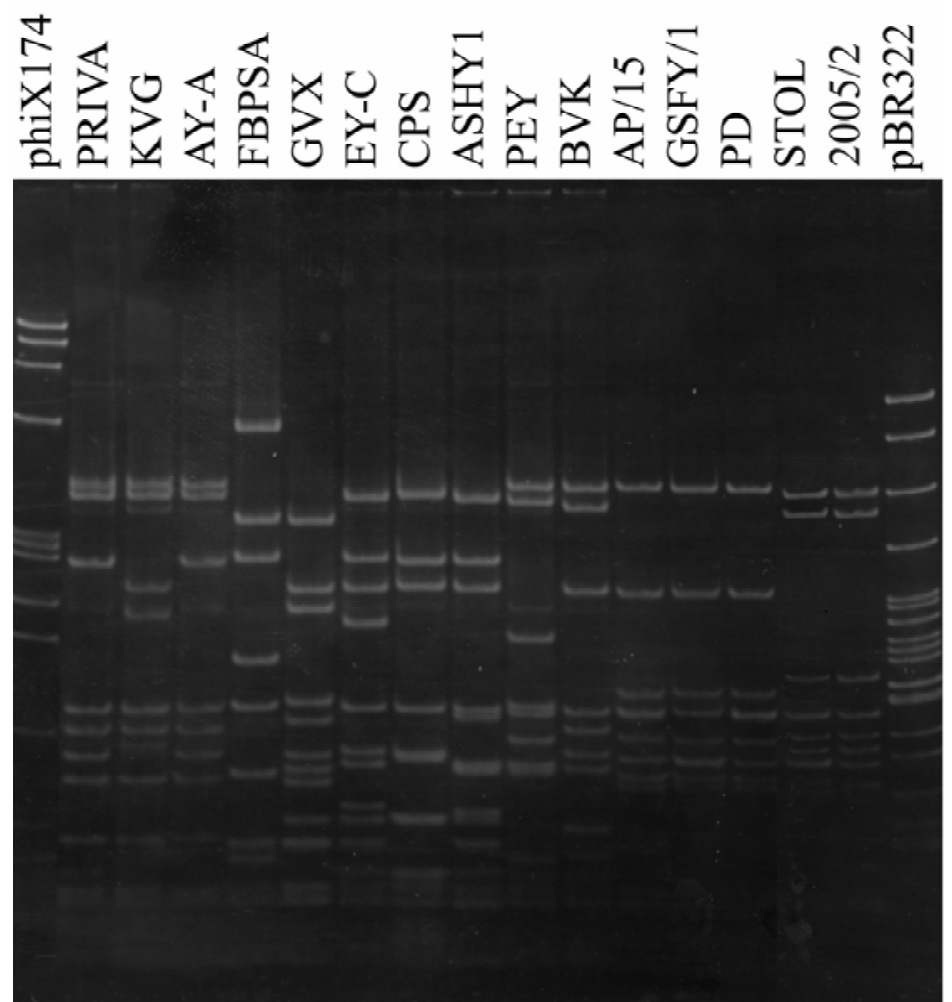

Fig. 1. A, Polyacrylamide gel 5\% showing TruI restriction fragment length polymorphism (RFLP) patterns of phytoplasma $16 \mathrm{~S}$ rDNA and spacer region obtained with $\mathrm{P} 1 / \mathrm{P} 7$ primer pair in direct polymerase chain reaction (PCR) from corn samples (2005/1 to 2005/16); acronyms are as reported in Table 1; phiX174, marker $\Phi X 174$ HaeIII digested, fragment sizes in base pairs from top to bottom: 1,353, 1,078, 872, 603, 310, 281, 271, 234, 194, 118, and 72; pBR322, marker pBR322 BsuRI digest, fragment sizes in bp, top to bottom: 587, 540, 502, 458, 434, 267, 234, 213, 192, 184, 124, 123, 104, 89, 80, 64, 57, and 51. B, Polyacrylamide gel 5\% showing TruI RFLP patterns of phytoplasma 16S rDNA and spacer region obtained with P1/P7 primer pair in direct PCR from a corn sample and from phytoplasma reference strains in periwinkle. Sample acronyms: PRIVA, primula phyllody; KVG, clover phyllody; AY-A, aster yellows from apricot; FBPSA, faba bean phyllody; GVX, Green Valley X disease; EY-C, elm yellows; CPS, Catharanthus phyllody; ASHY1, ash yellows; PEY, Pichris echioides yellows; BVK, flower stunting; AP/15, apple proliferation; GSFY/1, German European stone fruit yellows; PD, pear decline; and STOL, stolbur; 2005/2, corn sample 2005/2 (Table 1); phiX174, marker ФX174 HaeIII digested; fragment sizes in bp, top to bottom: 1,353, 1,078, 872, 603, 310, 281, 271, 234, 194, 118, and 72; pBR322, marker pBR322 MspI digest, fragment sizes in bp, top to bottom: $622,527,404,307,242,238,217,201,190,180,160,147,123,110,90,76$, and 67 .
TruI and Taq I restriction enzymes that were identical (Fig. 1A) and referable to the profile of stolbur phytoplasma, strain STOL, belonging to 16 SrXII-A ribosomal group (Fig. 1B). The four samples providing positive results in nested PCR assays with F1/B6 and R16(I)F1/R1 primer pairs, when digested with TruI restriction enzyme, showed restriction profiles identical to each other and referable to those of stolbur phytoplasma, strain STOL, belonging to $16 \mathrm{SrXII}-\mathrm{A}$ ribosomal group (data not shown).

Phylogenetic comparison of the $16 \mathrm{~S}$ rRNA gene of corn sample 2005/2 with 29 representative strains of the genus "Candidatus Phytoplasma" revealed that the phytoplasmas detected in corn are very closely related to the stolbur phytoplasmas (Fig. 2) and to other members of the 16SrXII group as defined previously $(16,18)$. The web search with blast-n on $16 \mathrm{~S}$ sequence (1,370 bp) of sample 2005/2 showed identity values of $99 \%$ with stolbur strains from Spanish, Chilean, and German grapevine yellows, respectively (AJ964960, AY739653, and X76428), with strain STOL from Serbian pepper (AF248959), and with stolbur strain from weed from Germany (X76427); 98\% similarity was observed with a clone of the stolbur strain from Chilean grapevine yellows (AY739654); and 97\% similarity with " $\mathrm{Ca}$. P. australiense".

Calculation of percent similarity values of spacer region sequences (168 bp) showed $100 \%$ identity between the phytoplasma detected in corn sample 2005/2 and the STOL strain (AF248959) isolated from pepper in Serbia, while different degrees of similarities, always above $90 \%$, were present with other phytoplasmas in 16SrXII group. Similarity lower than $90 \%$ was observed with the phytoplasma strain from maize bushy stunt (AF487779, 70\%) and from barley deformation (AY734453, $71 \%$ ) only (Table 3 ).

Tuf gene. In direct PCR assays with Tuf1f/Tuf1r primer pair, expected length amplicons $(1,080 \mathrm{bp})$ were obtained from 12 of 16 symptomatic samples, while no amplification was observed in the four asymptomatic samples. Through nested PCR with TufAyf/TufAyr primer pair, expected length fragments (940 bp) were obtained from all 16 symptomatic samples and from no asymptomatic ones (Table 1). Positive samples in nested PCR were subjected to RFLP analyses with TruI and HpaII restriction enzymes. All restriction profiles of corn samples obtained with HpaII were identical to each other and to control strains STOL, MO-2, and P1, and showed different profile from those of control strains VE-16 and MO-47 (Fig. 3). All restriction profiles of corn samples and of all control strains after RFLP analyses with $\operatorname{Tr} u \mathrm{I}$ restriction enzyme were identical to each other (data not shown).

Other chromosomal DNA. In direct PCR assays performed using G35p/m 
primer pair, expected length amplicons (1,200 bp) were obtained from 12 of 16 symptomatic samples, while four symptomatic and all four asymptomatic samples gave negative results (Table 1). RFLP profiles obtained with TruI, Tsp509I, and AluI restriction enzymes were identical to each other and to phytoplasma strain STOL used as control (data not shown). The 751bp sequence of corn sample 2005/2 obtained from $\mathrm{G} 35 \mathrm{p} / \mathrm{m}$ amplicon showed
$93 \%$ in nucleotide sequence similarity, and about $80 \%$ in amino acid sequence similarity with parts of the genome of " $\mathrm{Ca}$. P. asteris" (replicative DNA helicase of onion yellows phytoplasma, AP006628.1) (23).

\section{DISCUSSION}

Presence of stolbur phytoplasmas in corn samples with reddening symptoms is not only a new finding for Serbia; it is in fact the first report of stolbur phytoplasma

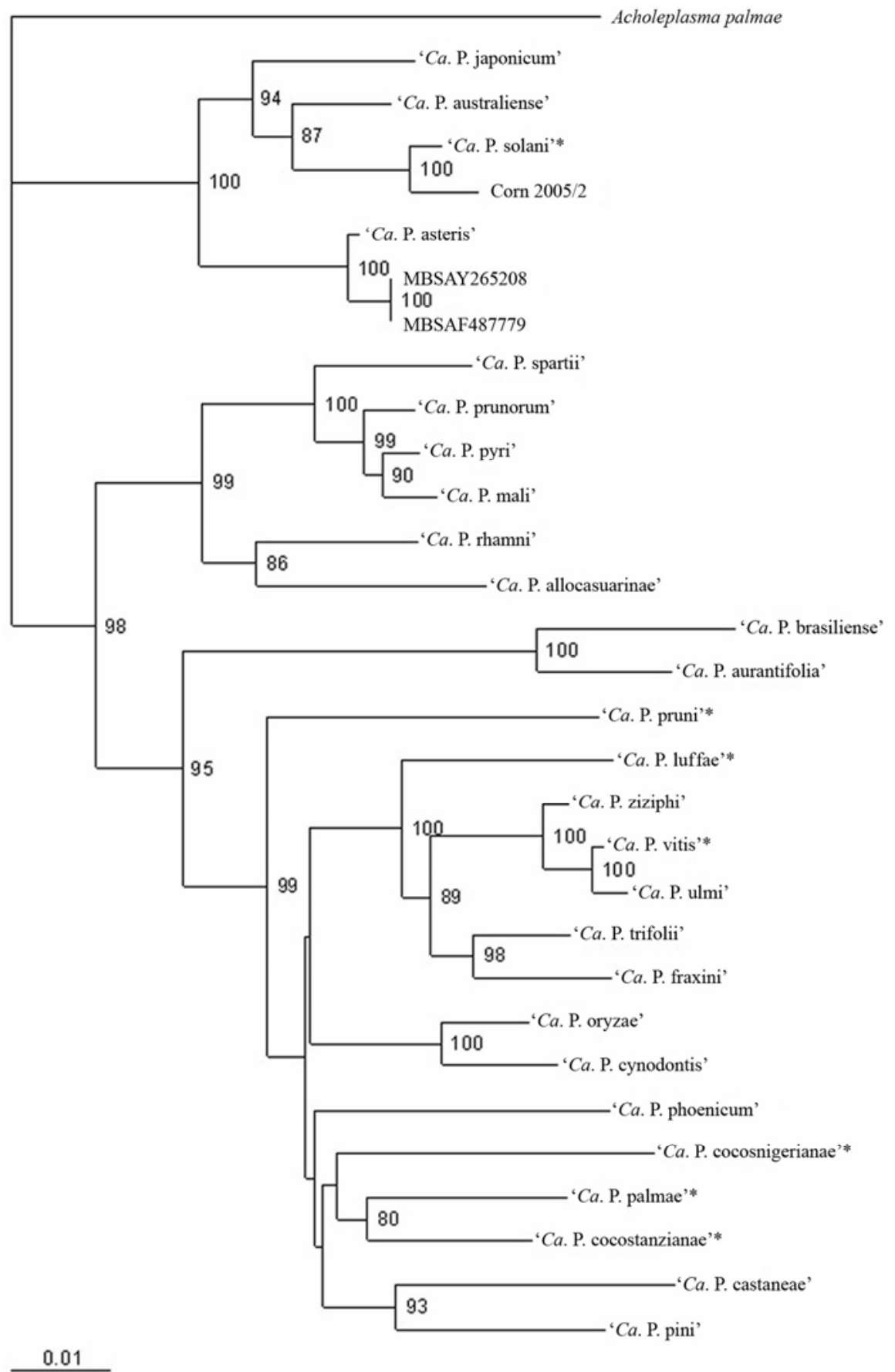

Fig. 2. Phylogenetic tree reporting placement of phytoplasma associated with corn sample $2005 / 2$ within the genus "Candidatus Phytoplasma". Asterisk (*) marks "Candidatus" names proposed at the X International Congress of the International Organization of Mycoplasmology, 1994, held in Bordeaux, France, but not yet formally described, and reported here as incidental citations which do not constitute prior citations, according to rule $28 \mathrm{~b}$ of the bacteriological code (15). Acholeplasma palmae was employed as the out-group taxon. Abbreviations are given in Table 2. Scale bar represents a phylogenetic distance of $1 \%$. in this species. Corn was reported to be infected with maize bushy stunt phytoplasma in the Americas where leaf reddening is a primary symptom associated with MBS disease (22). It is not uncommon, however, for different pathogens to be associated with indistinguishable symptoms in corn $(4,12,22)$.

Presence of phytoplasmas was demonstrated by the positive results of direct PCR on different phytoplasma genomic sequences, for example 16S rDNA and tuf, which are phylogenetically conserved genes, and $\mathrm{G} 35 \mathrm{p} / \mathrm{m}$ sequence, which is specific for phytoplasmas belonging to ribosomal groups $16 \mathrm{SrI}$ and $16 \mathrm{SrXII}$ $(7,34)$. All direct PCR assays (with P1/P7, Tuf1f $/ \mathrm{r}$, and G35p/m primer pairs) yielded consistent positive results, while nested PCR reactions (with primers F1/B6, $16 \mathrm{~S}(\mathrm{I}) \mathrm{F} 1 / \mathrm{R} 1$, and TufAyf/r) increased the sensitivity of the systems employed, allowing detection of stolbur phytoplasmas in all examined symptomatic corn samples. Negative results obtained by direct PCRs with template DNA from symptomatic plants can be the result of low titer and/or uneven phytoplasma distribution.

The phytoplasmas detected in corn with reddening symptoms were identified as belonging to stolbur, 16SrXII-A ribosomal subgroup, on the basis of RFLP analyses of 16S rDNA. Phylogenetic similarities of both 16S rDNA and spacer region se-

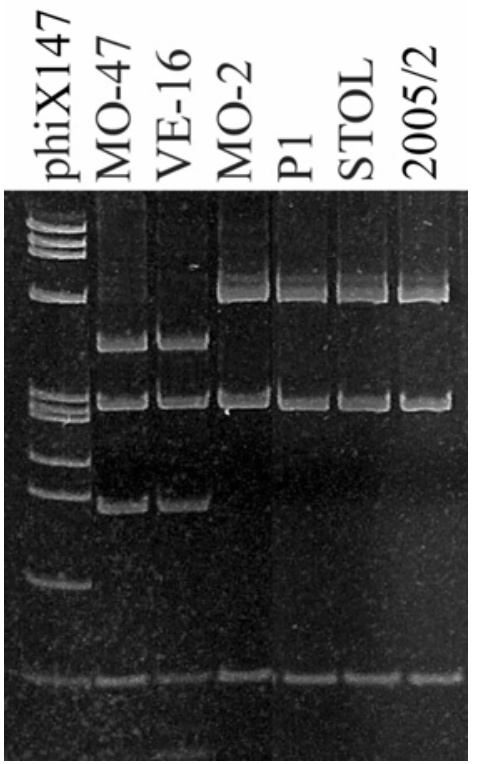

Fig. 3. Polyacrylamide gel showing restriction fragment length polymorphism (RFLP) results with HpaII restriction enzyme of the corn sample with reddening from Serbia infected with 16SrXII-A phytoplasmas and amplified in nested polymerase chain reaction (PCR) with TufAyf/r primers. Sample acronyms are: 2005/2, corn sample 2005/2 (Table 1); STOL, stolbur; $\mathrm{P} 1$, grapevine yellows from Serbia; VE-16, MO47, and MO-2, grapevine yellows from Venice and Modena provinces in Italy; phiX174, marker ФX174 HaeIII digested; fragment sizes in base pairs from top to bottom: 1,353, 1,078, $872,603,310,281,271,234,194,118$, and 72 . 
quences showed that corn 2005/2 strain has a very close molecular relationship with 16SrXII-A phytoplasmas (98 to $99 \%$ identity in $16 \mathrm{~S}$ and 98.7 to $100 \%$ identity in spacer region). The highest similarity was found between the phytoplasmas detected in corn and STOL phytoplasma reference strain from Serbian pepper, for which similarity was $99 \%$ in $16 \mathrm{~S}$ rDNA and $100 \%$ in spacer region sequences.

Tuf gene RFLP comparison was employed since it was shown to have higher genetic variability in phytoplasma molecular characterization than other genes (26). From RFLP analyses with HpaII, phytoplasmas detected in corn have restriction profile identical to reference strain STOL, strain P1 from grapevine with yellows from Serbia, and strain MO-2 from Italy. The reference strains VE-16 and MO-47 from grapevine with yellows from Italy had a different RFLP profile corresponding to the one described in stolbur phytoplasmas from grapevine and Urtica dioica in Germany and France (14).

The amplification of $\mathrm{G} 35 \mathrm{p} / \mathrm{m}$ sequence further confirmed data obtained with other genes in direct PCR, and therefore phytoplasma presence in symptomatic samples. The high homology of this sequence only with " $\mathrm{Ca}$. P. asteris", belonging to ribosomal subgroup $16 \mathrm{SrI}-\mathrm{B}$ retrieved by BLAST searches, reflects the fact that there are no additional sequences available in GenBank of this part of the genome belonging to any other phytoplasmas. " $\mathrm{Ca}$. P. asteris" is, at present, the only full phytoplasma sequence available in GenBank (23).

Since stolbur phytoplasmas were detected only in samples from symptomatic corn plants, it can be suggested that these phytoplasmas likely are involved in the reddening syndrome. However, more biological data must be obtained to confirm etiology of this corn reddening by fulfilling Koch's postulates.

Stolbur disease in Serbia was first noticed in 1949 on pepper (21). Since then, outbreaks of stolbur periodically have reduced productivity of Solanaceae plants, especially in dry years. The natural reservoir of stolbur disease in Serbia is the perennial, herbaceous weed Convolvulus arvensis (bindweed) (2). The most significant vector of stolbur was determined to be the Cixiid Hyalesthes obsoletus $(1,2,30)$, which overwinters on roots of $C$. arvensis. Activity of $H$. obsoletus in Serbia starts during the end of June or beginning of July, with maximum flight in the middle of July, and is followed by stolbur symptoms appearing on pepper at the end of July and becoming severe by the second half of August (2).

Recurrent epidemic outbreaks of corn reddening in the Banat region, especially in dry years as occurs for stolbur disease of Solanaceae plants, the development of reddening on corn at approximately the same time as stolbur on pepper $(2,30)$, and the great similarity $(99 \%$ in $16 \mathrm{~S}$ and $100 \%$ in spacer regions) between the stolbur phytoplasma detected in corn in 2005 and stolbur phytoplasma from pepper from Serbia, must be taken into consideration in further epidemiological studies.

The results of these findings could contribute to the start of corn reddening control. Knowledge about the genetic relationship of this stolbur strain of phytoplasma with other stolbur strains described previously on different plant species can help in further epidemiological work to identify insect vectors and possible weed or woody plant reservoir hosts of this prokaryote in the region where corn is grown. Knowing that corn is another host plant can also help with control measures to reduce the spread of stolbur phytoplasma in Serbian crops.

\section{ACKNOWLEDGMENTS}

The authors gratefully thank Prof. G. Firrao, University of Udine, Italy, for the help in phylogenetic analyses.

\section{LITERATURE CITED}

1. Aleksić, Ž., Šutić, D., and Aleksić, D. 1967. Transmission intensity of stolbur virus by means of Hyalesthes obsoletus Sign. on some host plants. Zaštita bilja 93-95:67-73.

2. Aleksić, Ž., Šutić, D., and Aleksić, D. 1969. A study of stolbur disease as a problem of pepper production in Yugoslavia. Zaštita bilja 105:235-239.

3. Blaženčić, J. 1982. Some anatomical characteristics of leaf and stem of maize with symptoms of redness. Bull. Institut Jardin Botaniques Université Beograd (XIII)XV:1-3.

4. Bradfute, O. E., Tsai, J. H., and Gordon, D. T. 1981. Corn stunt spiroplasma and viruses associated with a maize disease epidemic in southern Florida. Plant Dis. 65:837-841.

5. Chen, T. A., and Liao, C. H. 1975. Corn stunt spiroplasma: Isolation cultivation and proof of pathogenicity. Science 188:1015-1017.

6. Davis, R. E., and Lee, I.-M. 1993. Clusterspecific polymerase chain reaction amplification of 16S rDNA sequences for detection and identification of mycoplasmalike organisms. Phytopathology 83:1008-1011.

7. Davis, R. E., Prince, J. P., Hammond, R. W., Dally, E. L., and Lee, I.-M. 1992. Polymerase chain reaction detection of Italian Periwinkle Virescence mycoplasmalike organism (MLO) and evidence for relatedness with aster yellows MLOs. Petria 2:184-193.

8. Deng, S., and Hiruki, C. 1991. Amplification of 16S rRNA genes from culturable and nonculturable Mollicutes. J. Microbiol. Methods 14:53-61.

9. Duduk, B., Botti, S., Ivanović, M., Krstić, B., Dukić, N., and Bertaccini, A. 2004. Identification of phytoplasmas associated with grapevine yellows in Serbia. J. Phytopathol. 152:575-579.

10. Ebbert, M. A., Jeffers, D. P., Harrison, N. A., and Nault, L. R. 2001. Lack of specificity in the interaction between two maize stunting pathogens and field collected Dalbulus leafhoppers. Entomol. Exp. Aplicata 101:49-57.

11. Hall, T. A. 1999. Bio Edit: A user-friendly biological sequence alignment editor and analysis program for Windows 95/98/NT. Nucleic Acids Sympos. Ser. 41:95-98.

12. Harrison, N. A., Richardson, P. A., Tsai, J. H., Ebbert, M. A., and Kramer, J. B. 1996. PCR assay for detection of the phytoplasma associated with maize bushy stunt disease. Plant Dis. 80:263-269.
13. IRPCM 2004. 'Candidatus Phytoplasma', a taxon for the wall-less, non-helical prokaryotes that colonise plant phloem and insects. Int. J. Syst. Evol. Microbiol. 54:1243-1255.

14. Langer, M., and Maixner, M. 2004. Molecular characterization of grapevine yellows associated phytoplasmas of the Stolbur-group based on RFLP-analysis of non-ribosomal DNA. Vitis 43:191-199.

15. Lapage, S. P., Sneath, P. H. A., Lessel, E. F., Skerman, V. B. D., Seeliger, H. P. R., and Clarck, W. A. 1992. International code of nomenclature of bacteria: Bacteriological code. 1990 Revision. American Society for Microbiology, Washington, DC

16. Lee, I.-M., Gundersen, D. E., Davis, R. E., and Bartoszyk, I. M. 1998. Revised classification scheme of phytoplasmas based on RFLP analyses of $16 \mathrm{~S}$ rRNA and ribosomal protein gene sequences. Int. J. Syst. Bacteriol. 48:1153-1169.

17. Lee, I.-M., Gundersen, D. E., Hammond, R. W., and Davis, R. E. 1994. Use of mycoplasmalike organism (MLO) group-specific oligonucleotide primers for nested-PCR assays to detect mixed-MLO infections in a single host plant. Phytopathology 84:559-566.

18. Lee, I.-M., Gundersen-Rindal, D. E., and Bertaccini, A. 1998. Phytoplasma: Ecology and genomic diversity. Phytopathology 88:1359-1366.

19. Lee, I.-M., Gundersen-Rindal, D. E., Davis, R. E., Bottner, K. D., Marcone, C., and Seemüller, E. 2004. 'Candidatus Phytoplasma asteris', a novel phytoplasma taxon associated with aster yellows and related diseases. Int. J. Syst. Evol. Microbiol. 54:1037-1048.

20. Marić, A., and Savić, R. 1965. Dosadašnji rezultati istraživanja crvenila kukuruza. Dokumentacija za tehnologiju i tehniku u poljoprivredi: 8 .

21. Martinović, M., and Bjegović, P. 1950. O nekim bolestima i štetočinama utvrđenim u NR Srbiji u 1949 godini. Zaštita bilja 2:59-68.

22. Nault, L. R. 1980. Maize bushy stunt and corn stunt: A comparison of diseases symptoms, pathogen host ranges, and vectors. Phytopathology 70:659-662.

23. Oshima, K., Kakizawa, S., Nishigawa, H., Jung, H. Y., Wei, W., Suzuki, S., Arashida, R., Nakata, D., Miyata, S., Ugaki, M., and Namba, S. 2004. Reductive evolution suggested from the complete genome sequence of a plantpathogenic phytoplasma. Nat. Genet. 36(1):2729.

24. Padovan, A. C., Gibb, K. S., Bertaccini, A., Vibio, M., Bonfiglioli, R. E., Magarey, P. A., and Sears, B. B. 1995. Molecular detection of the Australian grapevine yellows phytoplasma and comparison with a grapevine yellows phytoplasma from Emilia-Romagna in Italy. Aust. J. Grape Wine Res. 1:25-31.

25. Prince, J. P., Davis, R. E., Wolf, T. K., Lee, I.M., Mogen, B. D., Dally, E. L., Bertaccini, A., Credi, R., and Barba, M. 1993. Molecular detection of diverse mycoplasmalike organisms (MLOs) associated with grapevine yellows and their classification with aster yellows, Xdisease, and elm yellows MLOs. Phytopathology 83:1130-1137.

26. Schneider, B., Gibb, K. S., and Seemüller, E. 1997. Sequence and RFLP analysis of the elongation factor $T u$ gene used in differentiation and classification of phytoplasmas. Microbiology 143:3381-3389.

27. Schneider, B., Seemüller, E., Smart, C. D., and Kirkpatrick, B. C. 1995. Phylogenetic classification of plant pathogenic mycoplasmalike organisms or phytoplasmas. Pages 369-380 in Molecular and Diagnostic Procedures in Mycoplasmology, Vol. 2. S. Razin, and J. G. Tully, eds. Academic Press, New York.

28. Starović, M., Tošić, M., Tomić, T., Živković, S., and Pavlović, S. 2004. Etiological study of 
redness on Maize. V Congr. Plant Prot., Zlatibor, November 22-26, 2004. Book of Abstracts. pp. 156-157.

29. Šutić, D. 1974. Virus diseases of Graminaeae identified in Yugoslavia. Mikrobiologija 11(2):127-132.

30. Šutić, D. 1983. Viroze biljaka. Nolit, Belgrade, Serbia. p. 205.

31. Šutić, D., Starović, M., Tošić, M., Stojanović, S., and Kuzmanović, S. 2003. Novija proučavanja crvenila kukuruza u nas. VI save- tovanje o zaštiti bilja, Zlatibor, November 2428, 2003. Book of Abstracts. p. 42.

32. Thompson, J. D., Gibson, T. J., Plewniak, F., Jeanmougin, F., and Higgins, D. G. 1997. The Clustal X windows interface: Flexible strategies for multiple sequence alignment aided by quality analysis tools. Nucleic Acids Res. 24:4876-4882.

33. Tolu, G., Botti, S., Garau, R., Prota, V. A., Sechi, A., Prota, U., and Bertaccini, A. 2006. Identification of a 16 SrII-E Phytoplasma in
Calendula arvensis, Solanum nigrum, and Chenopodium spp. Plant Dis. 90:325-330.

34. Vibio, M., Bertaccini, A., Lee, I.-M., Davis, R. E., and Clark, M. F. 1996. Differentiation and classification of aster yellows and related European phytoplasmas. Phytopathol. Mediterr. 35:33-42.

35. Williamson, D. L., and Whitcomb, R. F. 1975 Plant mycoplasmas: A cultivable spiroplasma causes corn stunt disease. Science 188:1018 1020 